\title{
MANAGEMENT OF OCCUPATIONAL RISK ANALYSIS OF EMPLOYEES RECOVERED FROM COVID-19 PANDEMIC -AN INDIVIDUAL CASE ANALYSIS
}

doi:10.2478/czoto-2021-0037

Date of submission of the article to the Editor: 15/12/2020

Date of acceptance of the article by the Editor: 31/03/2021

\section{Artur Woźny ${ }^{1}$-orcid id: 0000-0002-0294-0157 \\ ${ }^{1}$ Rzeszow University of Technology, Poland}

\begin{abstract}
In accordance with the applicable law, an employer cares for safe and hygienic working conditions. An occupational risk analysis isone of the elements determining the level of safety. The risks that may significantly contribute to the damage are identified through the activities related to the risk assessment. The role of an employer is to counteract these threats. The COVID-19 pandemic has had many negative consequences for the functioning of enterprises and the health and safety at work. The subject of the paper is to update the occupational risk among selected employees after the COVID-19 pandemic. Depending on the work environment, an employee is exposed to various types of risks that significantly affect not only health and safety, but also comfort, quality and work efficiency. COVID-19 causes various negative consequences, so it is important for the employer to monitor the employee's return process after the infection for a long time (approximately 2 months). Adjusting working conditions and temporarily reducing work intensity (expectations and work results) relatively increase the possibility of recovery and a faster return to full productivity.
\end{abstract}

Keywords: management, occupational risk management, occupational risk, COVID19

\section{INTRODUCTION}

Modern company management is largely based on change management. The change management is an implementation and supervision of new management principles and practices in businesses in order to improve their performance or introduce a strategic change. The progressing globalization changes make practically every economic entity implement major or minor changes. However, rules and practices change not only through the updating of normative acts or the economic situation (Drucker P.F., 1991).

The change management may be forced by unforeseen anomalies that appear in the social space in a local or global aspect. The emergence of the SarsCov-2 virus has brought about a lot of changes that companies had to adapt to. Depending on the scale of the pandemic, its stage (1st or 2 nd wave of infections), companies reacted 
differently to a given situation. It should be noted that in the case of Poland, the government reacted to the situation of entrepreneurs only after some time.

The first lockdown introduced in March 2020 was a big surprise for entrepreneurs who were naturally not prepared for such a threat. Despite the fact that enterprises usually anticipate problems and threats through appropriate management mechanisms, it was difficult to predict the scenario of a practically complete closure of the economy. Due to this situation, entrepreneurs were to a greater extent obliged to raise the standards of occupational health and safety.

\section{OCCUPATIONAL RISK}

According to Polish legislation, this is an employer who is responsible for the health and safety at work (pursuant to Art. 207 of the Labor Code). With the help of his knowledge and resources, he is to ensure such conditions of the working environment that not only comply with applicable law, standards, etc., but also he needs to ensure that employees are protected in a way that reduces the risk of accidents or diseases. From the management point of view, the OHS aspect should be important for the entrepreneur as it is in his interest that employees are ready to work as much as possible (Pacana, A., Czerwińska, K., Bednárová, 2019).

Proper health and safety management is usually verified in a crisis situation, i.e. an accident at work. Thanks to the analysis of the causes and circumstances of the event it is possible to determine whether there are real problems in a given work environment. Taking care of proper OHS management allows increasing the quality and efficiency of employees, and also improves the organizational culture. Building procedures, norms and rules prevailing inside the workplace is a long-term process that requires the involvement of all employees.

The employer has an ability to analyze threats in the workplace and counteract them. Thanks to the help of the health and safety inspector, he can assess the occupational risk at the workplace and implement the necessary preventive measures against threats. The basic requirements of occupational health and safety (related to occupational risk) were defined by the European Community in two directives:

- Council Directive of 12 June 1989 on the introduction of measures to increase the safety and health of workers at work (Directive 89/391 / EEC),

- Council Directive of June 14, 1989 on the approximation of the laws of the Member States relating to machinery (Directive 89/392 / EEC).

The European Community pays great attention to the nature of occupational health and safety in business management. According to the Regulation of the Minister of Labor and Social Policy, occupational risk is "the probability of adverse events related to the work performed, causing losses, in particular the occurrence of adverse health effects in employees as a result of occupational hazards occurring in the work environment or the way of work" (Saja P., Pacana A., Dobosz M., 2017).

One of the basic activities related to the organization of safe and hygienic work is the proper assessment of occupational risk at individual work stations. According to this definition, an employer is obliged to define all hazards that may appear in the work environment. The employer, with the help of the health and safety inspector, managers and the employees themselves, should strive for a proper assessment of the risks that may occur at the workplace. Art. 226 of the Labor Code indicates that: The employer "1) assesses and documents the occupational risk related to the work performed and applies the necessary preventive measures to reduce the risk, 2) 
informs employees about the occupational risk associated with the performed work, and principles of protection against threats "(Journal of Laws of 2014, item 1502).

\subsection{PROCESS OF OCCUPATIONAL RISK MANAGEMENT}

On the employer's request, the health and safety inspector performs an occupational risk assessment. This process takes place according to specific stages. One can distinguish:

- A job description,

- An analysis of the workplace along with observation of the selected employee during the implementation of daily activities,

- A documentation analysis:

o An analysis of work environment measurements, e.g. noise, dust, vibrations, etc.

o Documentation of occupational medicine doctors,

o Operating manuals for machines and devices,

o Work processes and operating procedures,

o Applicable normative acts regarding the type of workstations, e.g. transfer standards, work at height, etc.,

o An analysis of available personal protective equipment,

o Other elements resulting from the nature of the environment and workplace,

- Checklist for the occurrence of hazards in the workplace,

- Identification of threats,

- Risk assessment according to the selected method, e.g. PHA, Risc Score, etc.

- Definition of corrective and preventive actions.

By analyzing the work environment, observing an employee at work, as well as analyzing the medical documentation of the occupational medicine physician, the occupational health and safety inspector is able to properly identify and estimate the hazards at the workplace. It should be pointed out that the risk assessment process is multi-stage and it is up to the OHS inspector himself how diligently to approach the issue of assessment.

The literature on the subject distinguishes many assessment methods. The OHS inspector should choose the method which, in his opinion, will be the most appropriate for a given workplace or the specificity of the enterprise. Proper assessment of occupational risk really contributes to the improvement of working conditions since by determining the real threat, it is possible to implement corrective, preventive and reducing negative effects in the threats indicated in the document.

According to Polish legislation, an employer is obliged to inform an employee about the occupational risk assessment. Ignorance of the issues discussed in the risk assessment may result in a misinterpretation of the results by the employee himself, therefore it is important that the OHS inspector should participate in the process of informing about occupational risk. The method of documenting the familiarization of employees with the occupational risk is usually done by signing a list confirming the knowledge and understanding of the problem (Woźny A., Pacana A., 2017).

\subsection{SELECTED HAZARDS AT WORKPLACES}

While assessing the occupational risk, attention is paid to every possible hazard in the work environment. Usually they are divided into groups into physical, mechanical, biological and chemical hazards, etc. Depending on their type, they should be identified on the basis of e.g. the Dortmund list (created by a team led by G.C. Burger 
in 1964). It is possible to evaluate them thanks to proper identification. Depending on the work environment and the scope of activities, the scale of the risk may vary.

When analyzing individual aspects of the work environment, attention should be paid to the types of threats. In the cases analyzed, three characteristic threats were distinguished, which were affected by COVID-19:

- Overload of the musculoskeletal system,

- Mental burden,

- Psychosocial factors.

The specificity of the working environment and the scope of activities of a maintenance worker, an office worker and a teacher vary. Therefore, the causes and possible consequences of threats differ from each other. The measures to protect against threats are also important. At each of the workstations analyzed, there are different means of protection that can be used by an employee and an employer.

The maintenance worker performs various types of activities, mostly manually, where the musculoskeletal system may be overloaded mainly due to transport or other work requiring physical effort, including those carried out in a changing microclimate. The mental burden is also important due to the fact that the specificity of this work position requires a person to be multitasking and be able to use many machines and devices. This also has a direct impact on the psychosocial factor. The occurrence of time pressure related to sudden failures or problems indicates a significant threat (Gazda, A., Pacana, A., Malindžák, D., 2013).

Table 1.

Identification of selected threats for the position of the maintenance worker.

\begin{tabular}{|c|c|c|c|c|}
\hline \multirow{2}{*}{ Threat } & \multirow{2}{*}{$\begin{array}{l}\text { Threat source } \\
\text { (cause) }\end{array}$} & \multirow{2}{*}{$\begin{array}{c}\text { Possible } \\
\text { consequences of } \\
\text { the threat }\end{array}$} & \multicolumn{2}{|c|}{ Means of protection against threats } \\
\hline & & & Employee & Employer \\
\hline $\begin{array}{c}\text { Overload of } \\
\text { the } \\
\text { musculoskelet } \\
\text { al system }\end{array}$ & $\begin{array}{c}\text { Forced body position } \\
\text { - manual transport } \\
\text { work, work in } \\
\text { progress, physical } \\
\text { effort }\end{array}$ & $\begin{array}{l}\text { Back pain, back } \\
\text { pain, shoulder pain, } \\
\text { injuries of muscles } \\
\text { and tendons }\end{array}$ & $\begin{array}{l}\text { Compliance with } \\
\text { lifting standards } \\
\text { for men, work } \\
\text { organization }\end{array}$ & $\begin{array}{c}\text { Provides workplace } \\
\text { instructions at the } \\
\text { workplace }\end{array}$ \\
\hline Mental burden & $\begin{array}{l}\text { The pace of work, } \\
\text { responsibility for the } \\
\text { entrusted property }\end{array}$ & $\begin{array}{c}\text { Diseases of the } \\
\text { nervous and } \\
\text { digestive systems, } \\
\text { neuroses }\end{array}$ & $\begin{array}{c}\text { Proper } \\
\text { organization of } \\
\text { work and leisure }\end{array}$ & $\begin{array}{l}\text { Providing job } \\
\text { instructions for the } \\
\text { maintenance worker }\end{array}$ \\
\hline $\begin{array}{l}\text { Psychosocial } \\
\text { factors }\end{array}$ & $\begin{array}{l}\text { Complex tasks, time } \\
\text { pressure to complete } \\
\text { the task }\end{array}$ & $\begin{array}{l}\text { Neuroses, } \\
\text { depression, low self- } \\
\text { esteem in the } \\
\text { employee }\end{array}$ & $\begin{array}{l}\text { Limiting rush, } \\
\text { breaks at work }\end{array}$ & $\begin{array}{c}\text { Proper organization of } \\
\text { work }\end{array}$ \\
\hline
\end{tabular}

Source: author's own studies.

In the case of the office worker, the risks differ significantly than in the case of themaintenance worker. It should be pointed out that due to the sedentary work, as well as the forced position of the body in this workplace, there may be overload of the musculoskeletal system. The scope of responsibility in this type of work position often increases the risk of psychological burden and psychosocial factors. 
Table 2.

Identification of selected threats for the position of the office worker.

\begin{tabular}{|c|c|c|c|c|}
\hline Threat & Threat source & Possible & Means of protection against threats \\
\cline { 4 - 5 } & (cause) & $\begin{array}{c}\text { Ponsequences of the } \\
\text { threat }\end{array}$ & Employee & Employer \\
\hline $\begin{array}{c}\text { Overload of the } \\
\text { musculoskeletal } \\
\text { system }\end{array}$ & $\begin{array}{c}\text { Forced body position } \\
\text { - sitting at work with } \\
\text { a computer. }\end{array}$ & $\begin{array}{c}\text { Back pain, back pain, } \\
\text { shoulder pain, injuries } \\
\text { of muscles and } \\
\text { tendons }\end{array}$ & Breaks at work & $\begin{array}{c}\text { Provides workplace } \\
\text { instructions at the } \\
\text { workplace }\end{array}$ \\
\hline Mental burden & $\begin{array}{c}\text { Stress situations } \\
\text { resulting from the } \\
\text { awareness of the } \\
\text { consequences of } \\
\text { making mistakes }\end{array}$ & $\begin{array}{c}\text { Neuroses, depressive } \\
\text { states }\end{array}$ & Breaks at work & $\begin{array}{c}\text { Organization of } \\
\text { training courses for } \\
\text { employees on } \\
\text { coping with stress }\end{array}$ \\
\hline $\begin{array}{c}\text { Psychosocial } \\
\text { factors }\end{array}$ & $\begin{array}{c}\text { Complex tasks, time } \\
\text { pressure to complete } \\
\text { the task }\end{array}$ & $\begin{array}{c}\text { Neuroses, depression, } \\
\text { low self-esteem in the } \\
\text { employee }\end{array}$ & $\begin{array}{c}\text { Limiting rush, } \\
\text { breaks at work }\end{array}$ & $\begin{array}{c}\text { Proper organization } \\
\text { of work }\end{array}$ \\
\hline
\end{tabular}

Source: author's own studies.

The specificity of the teacher's work shows that he is exposed to a significant risk related to overloading the musculoskeletal system. Due to the standing position of the body and the constant need to bend over the student, negative health effects may occur. Constant contact with students and responsibility means that an important threat in the teaching position is the mental burden and psychosocial factors.

Table 3.

Identification of selected threats for the position of the teacher.

\begin{tabular}{|c|c|c|c|c|}
\hline \multirow{2}{*}{ Threat } & \multirow{2}{*}{$\begin{array}{l}\text { Threat source } \\
\text { (cause) }\end{array}$} & \multirow{2}{*}{$\begin{array}{c}\text { Possible } \\
\text { consequences of } \\
\text { the threat }\end{array}$} & \multicolumn{2}{|c|}{ Means of protection against threats } \\
\hline & & & Employee & Employer \\
\hline $\begin{array}{l}\text { Overload of the } \\
\text { musculoskelet } \\
\text { al system }\end{array}$ & $\begin{array}{l}\text { Forced body position } \\
\text { during classes - } \\
\text { standing position. }\end{array}$ & $\begin{array}{l}\text { Back pain, back } \\
\text { pain, shoulder } \\
\text { pain, injuries of } \\
\text { muscles and } \\
\text { tendons }\end{array}$ & $\begin{array}{l}\text { Work breaks } \\
\text { Compliance with } \\
\text { the workplace } \\
\text { instructions. }\end{array}$ & $\begin{array}{l}\text { Provides workplace } \\
\text { instructions at the } \\
\text { workplace }\end{array}$ \\
\hline Mental burden & $\begin{array}{l}\text { Stress related to the } \\
\text { education of young } \\
\text { people, responsibility } \\
\text { for the entrusted } \\
\text { property of the } \\
\text { educational institution }\end{array}$ & $\begin{array}{c}\text { Neuroses, } \\
\text { depressive states }\end{array}$ & $\begin{array}{l}\text { Breaks at work, } \\
\text { participation in } \\
\text { training sessions } \\
\text { on coping with } \\
\text { stress }\end{array}$ & $\begin{array}{l}\text { Organization of } \\
\text { training courses for } \\
\text { employees on coping } \\
\text { with stress }\end{array}$ \\
\hline $\begin{array}{l}\text { Psychosocial } \\
\text { factors }\end{array}$ & $\begin{array}{l}\text { Complex tasks, time } \\
\text { pressure to complete } \\
\text { the task }\end{array}$ & $\begin{array}{c}\text { Neuroses, } \\
\text { depression, low } \\
\text { self-esteem in the } \\
\text { employee }\end{array}$ & $\begin{array}{l}\text { Limiting rush, } \\
\text { breaks at work }\end{array}$ & $\begin{array}{c}\text { Proper organization of } \\
\text { work }\end{array}$ \\
\hline
\end{tabular}

Source: author's own studies.

An appropriate analysis of hazards in the workplace allows one to properly estimate the occupational risk. Only in this way the corrective and preventive actions can be defined reliably and correctly. The implementation of solutions improving health and safety at work allows you to achieve better quality and efficiency of work.

\subsection{UPDATING OF THE OCCUPATIONAL RISK AFTER RECOVERY FROM COVID-19 INFECTION}

COVID-19 infection can cause various complications that were not yet fully documented at the time of the pandemic. It should be pointed out that people who have been cured indicate different consequences of the infection. It should also be emphasized that complications may be important not only for the process of complete recovery, but also for the proper functioning of a person in society or work 
environment. During the update of threats after COVID-19, the occupational risk was reassessed. It should be noted that the analysis of individual cases of employees in the described positions confirms that the level of risk increases in some threats.

For the maintenance worker, there has been a change in the risk score for musculoskeletal overload from pre-infection to a significant level requiring risk reduction. The increased result is related to the fact that the employee, after infection, signals the periodic appearance of neuralgia in the lumbar spine. This state of affairs can significantly contribute to serious injury (David M.D., Bell M., 1997).

The risk related to mental burden in the case of this worker did not change over the course of the state before and after the COVID-19 infection. However, it should be noted that in the event of a threat with psychosocial factors, a significant increase in the risk took place (risk reduction required). The reason for such a situation is the reduced concentration, distraction, or states of weariness/fatigue that appear after infection.

Table 4.

Estimation of occupational risk of selected threats using the Risk Score method for the position of themaintenance worker before and after COVID-19 infection.

\begin{tabular}{|c|c|c|c|c|}
\hline $\begin{array}{l}\text { Name of the } \\
\text { occupational hazard } \\
\text { factor }\end{array}$ & $\begin{array}{c}\text { The severity of } \\
\text { possible } \\
\text { consequences } \\
\text { "S" }\end{array}$ & $\begin{array}{c}\text { Time of } \\
\text { exposure to the } \\
\text { hazard } \\
\text { "E" }\end{array}$ & $\begin{array}{c}\text { The } \\
\text { probability } \\
\text { of an event } \\
\text { "P" }\end{array}$ & $\begin{array}{c}\text { Score of } \\
\text { occupational risk } \\
\text { "R" }\end{array}$ \\
\hline \multicolumn{5}{|c|}{ Estimation formula: $\mathrm{S} \times \mathrm{E} \times \mathrm{P}=\mathrm{R}$} \\
\hline \multicolumn{5}{|c|}{ Before COVID-19 infection } \\
\hline \multirow{5}{*}{$\begin{array}{l}\text { Overload of the } \\
\text { musculoskeletal } \\
\text { system }\end{array}$} & Average & $\mathrm{E}=6$ & $P=3$ & Small risk \\
\hline & None & Daily & $\begin{array}{l}\text { Practically } \\
\text { possible }\end{array}$ & $\begin{array}{c}\text { Acceptable } \\
\text { Control needed }\end{array}$ \\
\hline & \multicolumn{4}{|c|}{ After COVID-19 infection } \\
\hline & Average & $E=6$ & $\mathrm{P}=3$ & Relevant risk \\
\hline & Severe body injury & Daily & $\begin{array}{l}\text { Practically } \\
\text { possible }\end{array}$ & $\begin{array}{c}\text { Essential } \\
\text { Risk reduction needed }\end{array}$ \\
\hline \multirow{6}{*}{ Mental burden } & \multicolumn{4}{|c|}{ Before COVID-19 infection } \\
\hline & Average & $\mathrm{E}=6$ & $\mathrm{P}=3$ & Small risk \\
\hline & None & Daily & $\begin{array}{l}\text { Practically } \\
\text { possible }\end{array}$ & $\begin{array}{c}\text { Acceptable } \\
\text { Control needed }\end{array}$ \\
\hline & \multicolumn{4}{|c|}{ After COVID-19 infection } \\
\hline & Average & $E=6$ & $\mathrm{P}=3$ & Small risk \\
\hline & None & Daily & $\begin{array}{l}\text { Practically } \\
\text { possible }\end{array}$ & $\begin{array}{c}\text { Acceptable } \\
\text { Control needed }\end{array}$ \\
\hline \multirow{6}{*}{ Psychosocial factors } & \multicolumn{4}{|c|}{ Before COVID-19 infection } \\
\hline & Average & $E=6$ & $\mathrm{P}=3$ & Small risk \\
\hline & None & Daily & $\begin{array}{l}\text { Practically } \\
\text { possible }\end{array}$ & $\begin{array}{c}\text { Acceptable } \\
\text { Control needed }\end{array}$ \\
\hline & \multicolumn{4}{|c|}{ After COVID-19 infection } \\
\hline & Average & $E=10$ & $P=6$ & Relevant risk \\
\hline & None & Daily & $\begin{array}{l}\text { Practically } \\
\text { possible }\end{array}$ & $\begin{array}{c}\text { Essential } \\
\text { Risk reduction needed }\end{array}$ \\
\hline
\end{tabular}

Source: author's own studies.

In the case of the office worker, there was also an increase in the risk score. As in the case of the maintenance worker, the office worker also experienced an increased risk of overloading the musculoskeletal system. The employee shows general pain in muscles and joints that have been present for a long time after recovery. In the case of mental strain and psychosocial factors, there was also a significant increase in risk to a significant level, requiring risk reduction. This state of affairs is caused by the fact that the employee experiences problems with concentration and attention, and is also more stressed than before the infection. 
Table 5.

Estimation of occupational risk of selected threats using the Risk Score method for the position of theoffice worker before and after COVID-19 infection.

\begin{tabular}{|c|c|c|c|c|c|c|}
\hline $\begin{array}{l}\text { Name of the } \\
\text { occupational hazard } \\
\text { factor }\end{array}$ & \multicolumn{2}{|c|}{$\begin{array}{l}\text { The severity of } \\
\text { possible } \\
\text { consequences } \\
\text { "S" }\end{array}$} & $\begin{array}{c}\text { Time of } \\
\text { exposure to the } \\
\text { hazard } \\
\text { "E" }\end{array}$ & $\begin{array}{c}\text { The } \\
\text { probability } \\
\text { of an event } \\
\text { "P" }\end{array}$ & & $\begin{array}{l}\text { ore of } \\
\text { tional risk } \\
\text { 'R" }\end{array}$ \\
\hline \multicolumn{7}{|c|}{ Estimation formula: $S \times E \times P=R$} \\
\hline \multirow{6}{*}{$\begin{array}{l}\text { Overload of the } \\
\text { musculoskeletal } \\
\text { system }\end{array}$} & \multicolumn{6}{|c|}{ Before COVID-19 infection } \\
\hline & $\mathrm{S}=3$ & Average & $\mathrm{E}=6$ & $\mathrm{P}=3$ & $\mathrm{R}=54$ & Small risk \\
\hline & \multicolumn{2}{|c|}{ None } & Daily & $\begin{array}{l}\text { Practically } \\
\text { possible }\end{array}$ & \multicolumn{2}{|c|}{$\begin{array}{c}\text { Acceptable } \\
\text { Control needed }\end{array}$} \\
\hline & \multicolumn{6}{|c|}{ After COVID-19 infection } \\
\hline & $\mathrm{S}=7$ & Average & $E=6$ & $\mathrm{P}=3$ & $\mathrm{R}=126$ & Relevant risk \\
\hline & \multicolumn{2}{|c|}{ Severe body injury } & Daily & $\begin{array}{l}\text { Practically } \\
\text { possible }\end{array}$ & \multicolumn{2}{|c|}{$\begin{array}{l}\text { Essential } \\
\text { Risk reduction needed }\end{array}$} \\
\hline \multirow{6}{*}{ Mental burden } & \multicolumn{6}{|c|}{ Before COVID-19 infection } \\
\hline & $S=3$ & Average & $E=6$ & $\mathrm{P}=3$ & $\mathrm{R}=54$ & Small risk \\
\hline & & ne & Daily & $\begin{array}{l}\text { Practically } \\
\text { possible }\end{array}$ & & $\begin{array}{l}\text { ptable } \\
\text { l needed }\end{array}$ \\
\hline & & & After CO & -19 infection & & \\
\hline & $\mathrm{S}=3$ & Average & $\mathrm{E}=10$ & $\mathrm{P}=6$ & $\mathrm{R}=180$ & Relevant risk \\
\hline & & ne & $\begin{array}{l}\text { Permanent } \\
\text { exposure }\end{array}$ & $\begin{array}{c}\text { Practically } \\
\text { possible }\end{array}$ & Risk & $\begin{array}{l}\text { ential } \\
\text { ction needed }\end{array}$ \\
\hline \multirow{6}{*}{ Psychosocial factors } & \multicolumn{6}{|c|}{ Before COVID-19 infection } \\
\hline & $S=3$ & Average & $E=6$ & $\mathrm{P}=3$ & $\mathrm{R}=54$ & Small risk \\
\hline & \multicolumn{2}{|c|}{ None } & Daily & $\begin{array}{l}\text { Practically } \\
\text { possible }\end{array}$ & \multicolumn{2}{|c|}{$\begin{array}{c}\text { Acceptable } \\
\text { Control needed }\end{array}$} \\
\hline & \multicolumn{6}{|c|}{ After COVID-19 infection } \\
\hline & $\mathrm{S}=7$ & Average & $E=6$ & $\mathrm{P}=3$ & $\mathrm{R}=126$ & Relevant risk \\
\hline & \multicolumn{2}{|c|}{ Severe body injury } & Daily & $\begin{array}{l}\text { Practically } \\
\text { possible }\end{array}$ & \multicolumn{2}{|c|}{$\begin{array}{c}\text { Essential } \\
\text { Risk reduction needed }\end{array}$} \\
\hline
\end{tabular}

Source: author's own studies.

The greatest change in risk was recorded for an employee holding the position of the teacher. While the risk in the employee with respect to the musculoskeletal system did not change (the analyzed employee did not report any significant complications related to the system), significant changes took place in the case of psychological stress and psychosocial factors. There is a high risk that needs to be reduced immediately. The employee indicated that return to work after infection (including remote work) causes great anxiety and depression.

Table 6.

Estimation of occupational risk of selected threats using the Risk Score method for the position of theteacher before and after COVID-19 infection.

\begin{tabular}{|c|c|c|c|c|c|c|}
\hline $\begin{array}{l}\text { Name of the } \\
\text { occupational hazard } \\
\text { factor }\end{array}$ & $\begin{array}{r}\text { The } \\
\mathrm{p} \\
\text { con }\end{array}$ & $\begin{array}{l}\text { verity of } \\
\text { sible } \\
\text { quences } \\
\text { S" }\end{array}$ & $\begin{array}{c}\text { Time of } \\
\text { exposure to the } \\
\text { hazard } \\
\text { "E" }\end{array}$ & $\begin{array}{c}\text { The } \\
\text { probability } \\
\text { of an event } \\
\text { "P" }\end{array}$ & \multicolumn{2}{|c|}{$\begin{array}{c}\text { Score of } \\
\text { occupational risk } \\
\text { "R" }\end{array}$} \\
\hline \multicolumn{7}{|c|}{ Estimation formula: $\mathbf{S} \times \mathbf{E} \times \mathbf{P}=\mathbf{R}$} \\
\hline \multicolumn{7}{|c|}{ Before COVID-19 infection } \\
\hline \multirow{5}{*}{$\begin{array}{l}\text { Overload of the } \\
\text { musculoskeletal } \\
\text { system }\end{array}$} & $\mathrm{S}=3$ & Average & $E=6$ & $\mathrm{P}=3$ & $\mathrm{R}=54$ & Small risk \\
\hline & \multicolumn{2}{|c|}{ None } & Daily & $\begin{array}{l}\text { Practically } \\
\text { possible }\end{array}$ & \multicolumn{2}{|c|}{$\begin{array}{c}\text { Acceptable } \\
\text { Control needed }\end{array}$} \\
\hline & \multicolumn{6}{|c|}{ After COVID-19 infection } \\
\hline & $\mathrm{S}=3$ & Average & $E=6$ & $\mathrm{P}=3$ & $\mathrm{R}=54$ & \\
\hline & \multicolumn{2}{|c|}{ None } & Daily & $\begin{array}{l}\text { Practically } \\
\text { possible }\end{array}$ & \multicolumn{2}{|c|}{$\begin{array}{c}\text { Acceptable } \\
\text { Control needed }\end{array}$} \\
\hline \multirow{3}{*}{ Mental burden } & \multicolumn{6}{|c|}{ Before COVID-19 infection } \\
\hline & $S=3$ & Average & $E=6$ & $P=3$ & $R=54$ & Ryzyko małe \\
\hline & \multicolumn{2}{|c|}{ None } & Daily & $\begin{array}{l}\text { Practically } \\
\text { possible }\end{array}$ & \multicolumn{2}{|c|}{$\begin{array}{c}\text { Acceptable } \\
\text { Control needed }\end{array}$} \\
\hline
\end{tabular}




\begin{tabular}{|c|c|c|c|c|c|c|}
\hline & \multicolumn{6}{|c|}{ After COVID-19 infection } \\
\hline & $\mathrm{S}=7$ & Large & $E=6$ & $\mathrm{P}=6$ & $\mathrm{R}=252$ & Large risk \\
\hline & Seve & ody injury & Daily & $\begin{array}{c}\text { Quite } \\
\text { possible }\end{array}$ & Immec & $\begin{array}{l}\text { Large } \\
\text { ate risk reduction } \\
\text { needed }\end{array}$ \\
\hline \multirow{6}{*}{ Psychosocial factors } & \multicolumn{6}{|c|}{ Before COVID-19 infection } \\
\hline & $\mathrm{S}=3$ & Average & $E=6$ & $\mathrm{P}=3$ & $\mathrm{R}=54$ & Small risk \\
\hline & \multicolumn{2}{|c|}{ None } & Daily & $\begin{array}{l}\text { Practically } \\
\text { possible }\end{array}$ & \multicolumn{2}{|c|}{$\begin{array}{c}\text { Acceptable } \\
\text { Control needed }\end{array}$} \\
\hline & \multicolumn{6}{|c|}{ After COVID-19 infection } \\
\hline & $\mathrm{S}=7$ & Average & $E=6$ & $P=3$ & $R=126$ & Ryzyko istotne \\
\hline & \multicolumn{2}{|c|}{ Severe body injury } & Daily & $\begin{array}{l}\text { Practically } \\
\text { possible }\end{array}$ & \multicolumn{2}{|c|}{$\begin{array}{c}\text { Essential } \\
\text { Risk reduction needed }\end{array}$} \\
\hline
\end{tabular}

Source: author's own studies.

\section{CONCLUSIONS}

Shaping safe working conditions is a continuous process. Therefore, an employer should constantly monitor not only the working environment conditions, but also the health changes of the employees themselves. It should be emphasized that COVID19 infection causes many different complications (so far little identified), which may contribute (temporarily or permanently) to an increase in occupational risk in some threats, as evidenced by the need to update the risk in the analyzed cases much more often.

In Polish legislation, the necessity to perform medical control examinations (occupational medicine) is necessary when an employee is incapable of work for more than 30 days. Therefore, after the infection, the employee often has no such tests. It seems reasonable to send an employee for an examination in the event of COVID-19 infection so that the occupational medicine physician assesses the employee's ability to perform work. Actions should be taken to conduct tests as widely as possible in order to determine whether the employee after illness has damaged various organs (general tests - blood analysis, X-ray of the lungs, using the voice at work - an ENT, phoniatrist or audiologist).

\section{REFERENCES}

Saja, P., Woźny, A., Pacana, A., Dobosz, M., 2017. Additional Components of Risk Assessment and Their Impact on the Probability Parameter, Production Engineering Archives, 14.

Woźny, A., Pacana, A., 2017. Synthetische Auffassung der Methoden für Gefährdungsbeurteilung, Franciszek Hadam Euro-Capitol, Friedrichshafen.

Pacana, A., Czerwińska, K., Bednárová, L., 2019. Comprehensive improvement of the surface quality of the diesel engine piston, Metalurgija, 58 (3-4), 329-332.

Gazda, A., Pacana, A., Malindžák, D. 2013 Study on improving the quality of stretch film by Taguchi method, Przemysł Chemiczny, 92 (6), 980-982.

Drucker, P.F., 1991. Management - Tasks, Responsibilities and Practices, William Heinemann, London.

Parker M., 2002. Against Management, Polity Press, Cambridge.

David, M.D., Bell, M., 1997. Occupational risk of human immunodeficiency virus infection in healthcare workers: An overview, The American Journal of Medicine 102 (5), 2, 9-15.

Ustawa z dnia 26.06.1974 r. Kodeks pracy (Dz.U. 2014 poz. 1502).(Act of June 26, 1974, Labor Code (Journal of Laws of 2014, item 1502). 